\title{
Reduction of microbiota in marinated vacuum-packaged poultry breast fillets
}

\author{
Jelena Janjic ${ }^{*}$, Jelena Ciric ${ }^{2}$, Slaven Grbic ${ }^{3}$, Marija Boskovic ${ }^{1}$, Milica Glisic ${ }^{1}$, Radmila Mitrovic ${ }^{2}$, \\ Adriana Radosavac ${ }^{4}$, Milan Z. Baltic ${ }^{1}$
}

A b s tr a c t: The aim of this study was to determine the effect of different marinade solution on the microbiome of chicken breast fillets packaged under vacuum and stored at $4^{\circ} \mathrm{C}$. Three types of marinade were tested. A total of 120 chicken breast fillets were marinated in control $(6 \% \mathrm{NaCl})$ or three different marinades: $6 \% \mathrm{NaCl}$ and $2 \%$ sodium tripolyphosphate; $6 \% \mathrm{NaCl}$ and $2 \%$ sodium citrate, and; $6 \% \mathrm{NaCl}, 1 \%$ sodium tripolyphosphate and 1\% sodium citrate. Microorganisms were enumerated on the first day of testing (day $0)$ and on days 7, 14, 21 and 28 of chilled storage. Marination resulted in significant differences $(p<0.05)$ in the numbers of total viable counts, Enterobacteriaceae, lactic acid bacteria and anaerobic bacteria counts. The combination of $6 \% \mathrm{NaCl}$ and $2 \%$ sodium citrate is the most appropriate marinade option for reducing the growth of the examined bacterial groups in vacuum-packaged marinated chicken breast fillets during chilled storage.

Keywords: poultry meat, shelf life, spoilage bacteria, storage conditions.

\section{Introduction}

Spoilage of meat occurs as a consequence of the growth and metabolic activities of spoilage bacteria. During meat storage, the dominant microbiota can cause product deterioration and release of volatile compounds or formation of slime, resulting in a product unacceptable for human consumption The presence and growth of bacterial contaminants occurring in poultry meat depend on different practices that are using for ensuring microbial quality, such as duration and temperature of storage, composition of marinade and gas composition used for storage under modified atmosphere packaging (MAP) or vacuum packaging (Kreyenschmidt et al., 2010; Baltic et al., 2015; Rouger et al., 2017).

Many studies show the influence of marination on tenderness, texture, moisture, water-holding capacity, oxidative stability and yields of poultry breast. Due to the increasing need of consumers to maintain the freshness of chicken for as long a period of time, both in store and in households, it is necessary to control the bacterial microbiota in chicken meat products (Petracci et al., 2014; Kim et al., 2015; Mathew et al., 2016).

The need for fresh food suitable for supply to distant markets has increased the interest in procedures for extending the shelf-life of meat and meat products. Obviously, this time should include not only the time needed to reach the markets but an additional period encompassing retail refrigerated storage and then storage at the consumer's home, as product could be used some days after purchase. Therefore, this issue has become a great challenge to chicken producers. Chicken is a highly perishable food, and the time it takes to deteriorate varies from 4 to about 10 days after slaughter, in spite of it being stored under chill systems (Marenzi, 1986). Deterioration depends on the microbiological quality of the poultry carcasses, which is a direct reflection of sanitation during slaughtering and handling practices. Chicken and other types of poultry have higher pathogenic and spoilage bacterial counts than almost any other food (Snyder, 1998). However, marinade treatments and vacuum packaging can have benefits with respect to the shelf-life, sensory

\footnotetext{
${ }^{1}$ University of Belgrade, Faculty of veterinary medicine, Bulevar Oslobodjenja 18, 11000 Belgrade, Serbia;

2Institute for Meat Hygiene and Technology, Belgrade, Kacanskog 13, 11000 Belgrade, Serbia;

${ }^{3}$ Pan-European University Apeiron, Faculty of Health Sciences, Pere Krece 13, 78000 Banja Luka, Republika Srpska, Bosnia and Herzegovina;

${ }^{4}$ Faculty of Applied Management, Economics and Finance (MEF), Jevrejska Street no. 24/1,11000 Belgrade, Serbia.
}

*Corresponding Author: Janjic Jelena, jeckonbg@gmail.com 
characteristics and quality attributes of chicken meat (Buses and Thompson, 2003; Piñon et al., 2015). Storage temperature and type of packaging are selective for different bacterial populations.

The aim of this study was to determine the effect of different marinades on the microbiome of skinless chicken breast fillets packaged under vacuum and stored at $4^{\circ} \mathrm{C}$.

\section{Materials and Methods}

\section{Chicken breast fillets and marinades}

A total of 120 chicken breasts fillets, without skin, approximately $0.1 \mathrm{~kg}$ each, were obtained from a local slaughterhouse. They were taken from the production line and transported under refrigeration to the laboratory within a few hours.

Skinless breasts fillets were divided into four groups. Control, (C) fillets were marinated in a $6 \%$ $\mathrm{NaCl}$ solution. E1 fillets were marinated in $6 \% \mathrm{NaCl}$ $+2 \%$ sodium tripolyphosphate (STP) (Merck). E2 fillets were marinated in $6 \% \mathrm{NaCl}+2 \%$ sodium citrate (Merck). E3 fillets were marinated in $6 \% \mathrm{NaCl}$, $1 \%$ STP and $1 \%$ sodium citrate. The chicken meat weight-to-marinade volume ratio was 1:2. After five hours of marinating, fillets were individually vacuum-packaged in plastic bags. The air was removed from the bags and they were then heat-sealed. Vacuum-packaged chicken breast fillets were stored at $4^{\circ} \mathrm{C}$. On each sampling day (days $0,7,14,21$ and 28 of storage), three packages from each treatment were randomly selected analysed for total viable counts (TVCs), Enterobacteriaceae, lactic acid bacteria (LAB) and anaerobic bacteria counts. Production of strong off-odours and unacceptable general aspects determined when to stop analysis.

\section{Microbiological analysis}

Chicken breasts were aseptically sampled on each sampling day by removing $10 \mathrm{~g}$ of fillet meat. The $10 \mathrm{~g}$ amounts were homogenised, subjected to tenfold serial dilution in buffered peptone water (BPW) and analysed by surface plating. TVCs were determined using plate count agar (PCA, Merck) after incubation at $30^{\circ} \mathrm{C}$ for 3 days. For counting the number of Enterobacteriaceae, the pour-plate method on violet red bile glucose (VRBG) agar (Merck) was used. Plates were incubated at $37^{\circ} \mathrm{C}$ for $24 \pm 2$ hours. After plating on a suitable substrate, MRS Agar (Merck) and PCA (Merck), LAB and anaerobic bacteria, respectively, were incubated at $25^{\circ} \mathrm{C}$ for 3 days in an anaerobic jar (Merck) with an anaerobic generating gas pack (Merck). The colony forming units per gram $(\mathrm{CFU} / \mathrm{g})$ on duplicate countable plates were averaged to determine bacterial counts for each fillet and expressed as logarithms.

\section{Statistical analysis}

For statistical analysis, all logarithms of bacterial counts were expressed as mean \pm standard deviation (SD). Statistical analysis of the results obtained was conducted using Microsoft Office Excel 2010 and GraphPad Prism software, version 7.00 for Windows (GraphPad Software, San Diego, California USA, www.graphpad.com). The effects of marination treatment were compared between days, and also different marinade treatments were compared on the same testing day, using one-factor analysis of variance (ANOVA). Statistical significance was at the level of $\mathrm{p}<0.05$. Bacterial count trends for TVC, Enterobacteriaceae, LAB and anaerobic bacteria during the storage period are presented graphically (Microsoft Office, Excel, 2010).

\section{Results and Discussion}

TVCs on the chicken fillets increased during the storage time in all marinade treatments, except E2. The highest TVCs were in C and E1 fillets $(7.03 \log \mathrm{CFU} / \mathrm{g}, 6.94 \mathrm{log} \mathrm{CFU} / \mathrm{g}, \mathrm{P}>0.05$, respectively) (Fig. 1). However, the number of TVC was significantly lower $(\mathrm{P}>0.05)$ in E2 fillets than in the other marinade treatments on all days $(0,7,14,21$, and 28$)$ (Table 1$)$. The highest TVC ( $7.03 \pm 0.23 \log$ CFU/g) was on day 28 in control fillets (Table 1). Meat spoilage results in the development of off-odours and slime formation, making the meat unacceptable for human consumption (Iulietto et al., 2015; Ercolini et al., 2006; Jay, 2000). According to many studies (Nychas et al., 2008; Buses and Thompson, 2003; Hollingsworth, 2000), off-odours in chicken meat develop when TVCs approach 7.2 to $8.0 \log \mathrm{CFU} / \mathrm{g}$, so our TVCs were slightly lower than this on day 28 , when we decided the off-odour and appearance of the chicken fillets were unacceptable.

The type of marinade and storage conditions affected the decrease in the number of Enterobacteriaceae during storage. Specifically, significantly lower numbers of Enterobacteriaceae (2.70 log CFU/g, $2.64 \log \mathrm{CFU} / \mathrm{g}, \mathrm{p}<0.05$, respectively) were found in fillets marinated with $1 \%$ and $2 \%$ sodium citrate than in the other two marinades, 


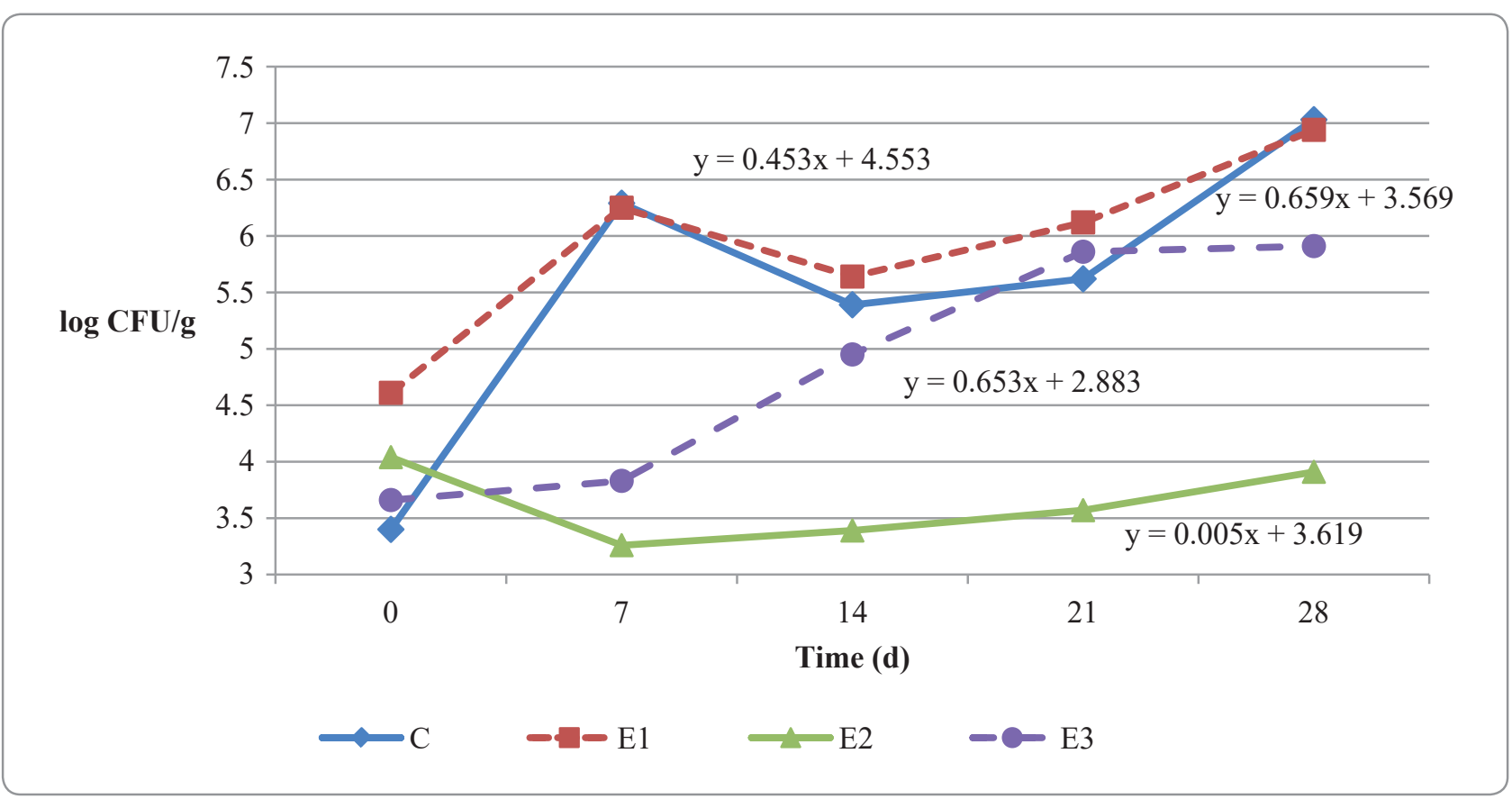

Figure 1. Total viable counts $(\log \mathrm{CFU} / \mathrm{g})$ in control $(\mathrm{C})$ and marinated (E1, E2 and E3) vacuum-packaged skinless chicken breast fillets $(n=120)$

while the addition of $2 \%$ sodium citrate decreased the Enterobacteriaceae count by $0.85 \log \mathrm{CFU} / \mathrm{g}$ by day 28 (Fig. 2, Table 1). Due to the inconsistency of these results, further tests should be conducted to determine which marinade ingredients improve the reduction of Enterobacteriaceae counts.
Enterobacteriaceae are one of the potential bacterial spoilage groups of poultry meat. However, the involvement of these bacteria and their role in poultry meat spoilage is not completely clarified. Some marinade treatments effectively inhibited coliform growth (Buses and Thompson, 2003). Nonetheless, different

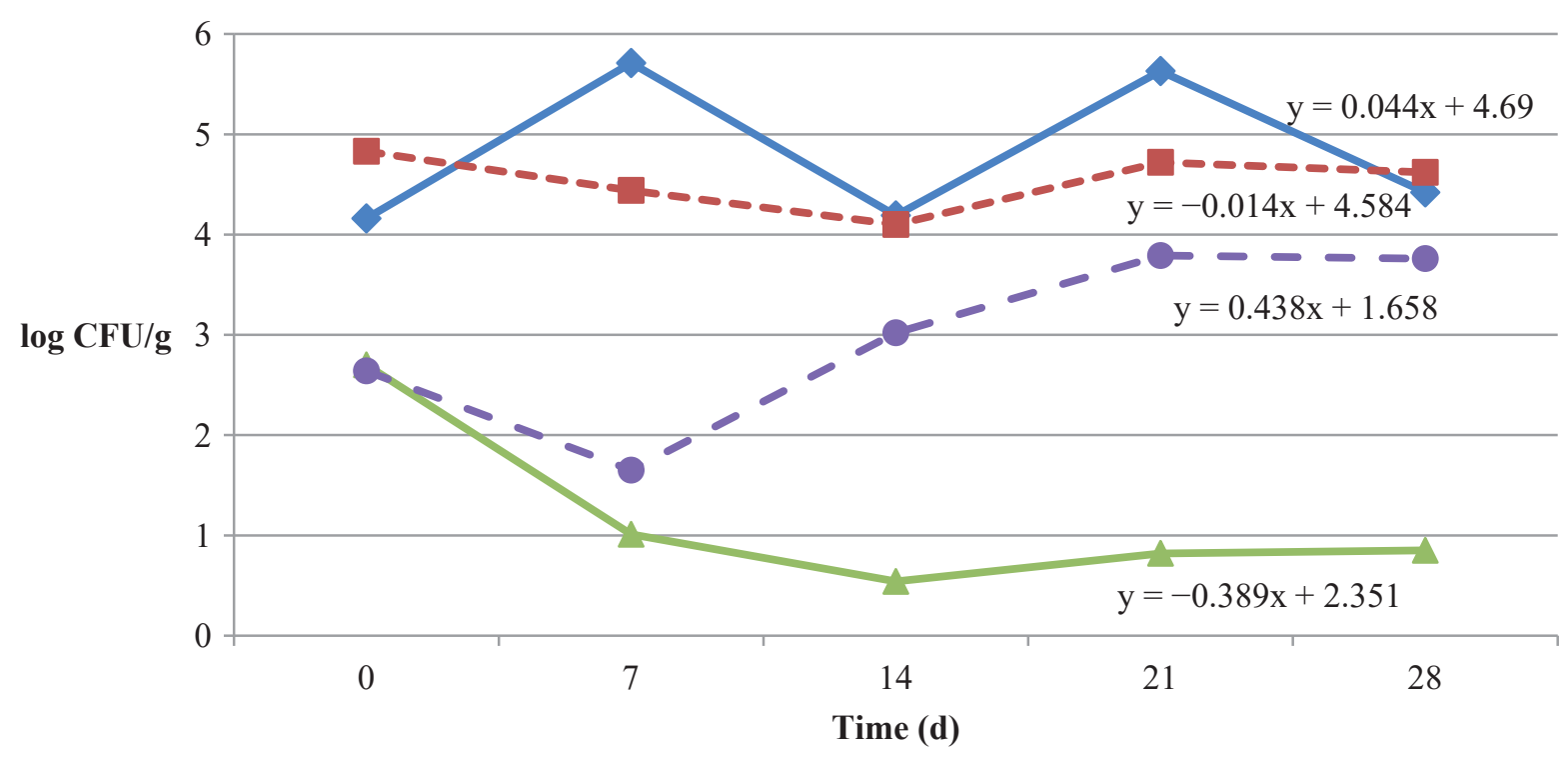

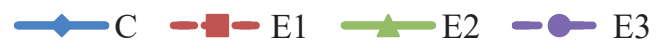

Figure 2. Enterobacteriaceae counts (log CFU/g) in control (C) and marinated (E1, E2 and E3) vacuum-packaged skinless chicken breast fillets $(n=120)$ 


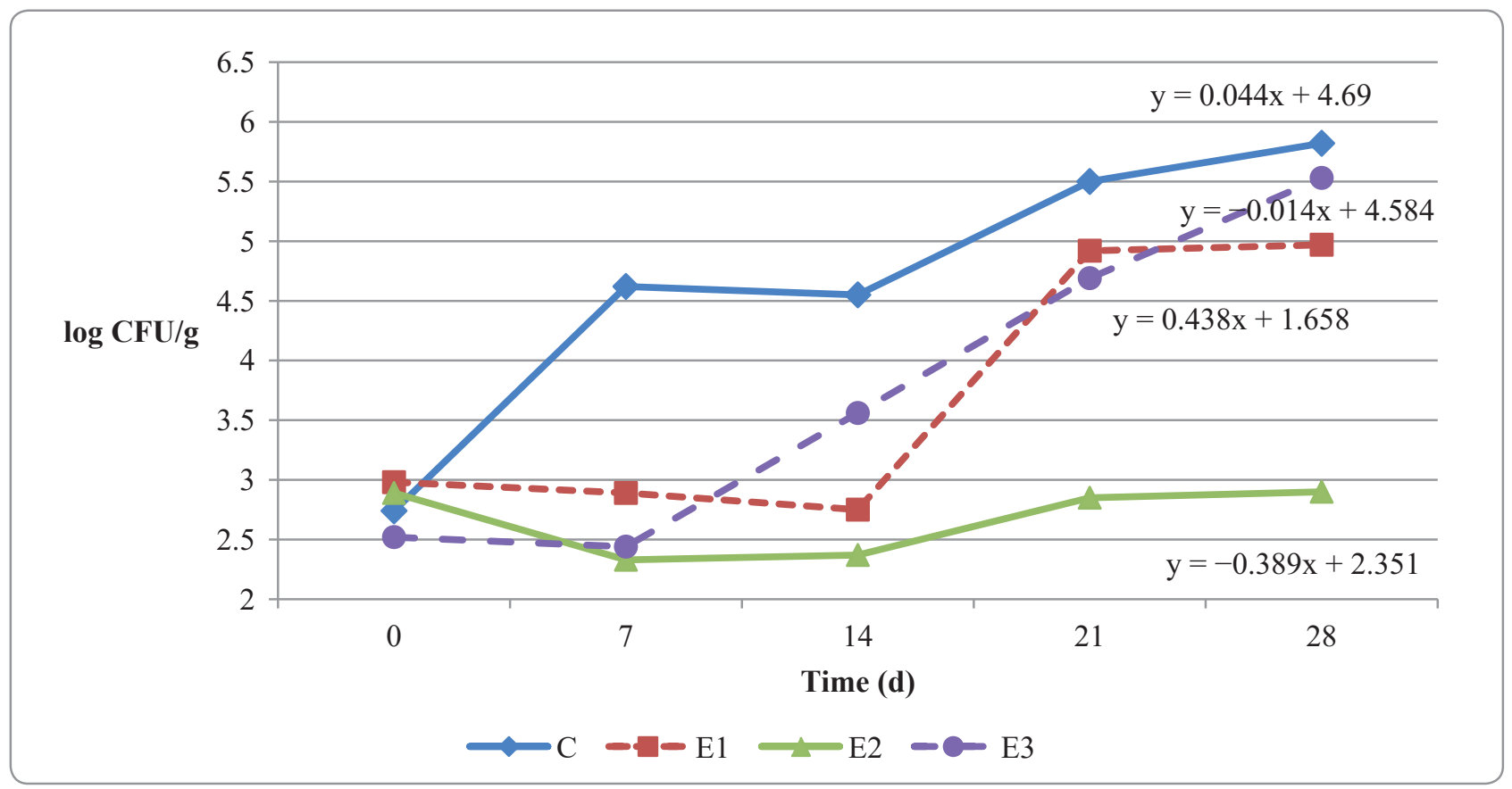

Figure 3. Lactic acid bacteria counts (log CFU/g) in control (C) and marinated (E1, E2 and E3) vacuum-packaged skinless chicken breast fillets $(n=120)$

packaging types did not affect Enterobacteriaceae counts (Rouger et al., 2017). The number of Enterobacteriaceae on spoiled chicken meat varies (Balamatsia et al., 2007; Doulgeraki et al., 2012; Zhang et al., 2012). Enterobacteriaceae numbers on marinated poultry ranged from $6.0 \log \mathrm{CFU} / \mathrm{g}$ (stored at $4^{\circ} \mathrm{C}, 15$ days) to $8.36 \log \mathrm{CFU} / \mathrm{g}$ (stored at 4 to $10^{\circ} \mathrm{C}, 4$ days). Also, Enterobacteriaceae were not detected in spoiled poultry meat in some studies, regardless of the duration and temperature of storage (Al-Nehlawi et al., 2013; Chouliara et al., 2007; Capita et al., 2013).

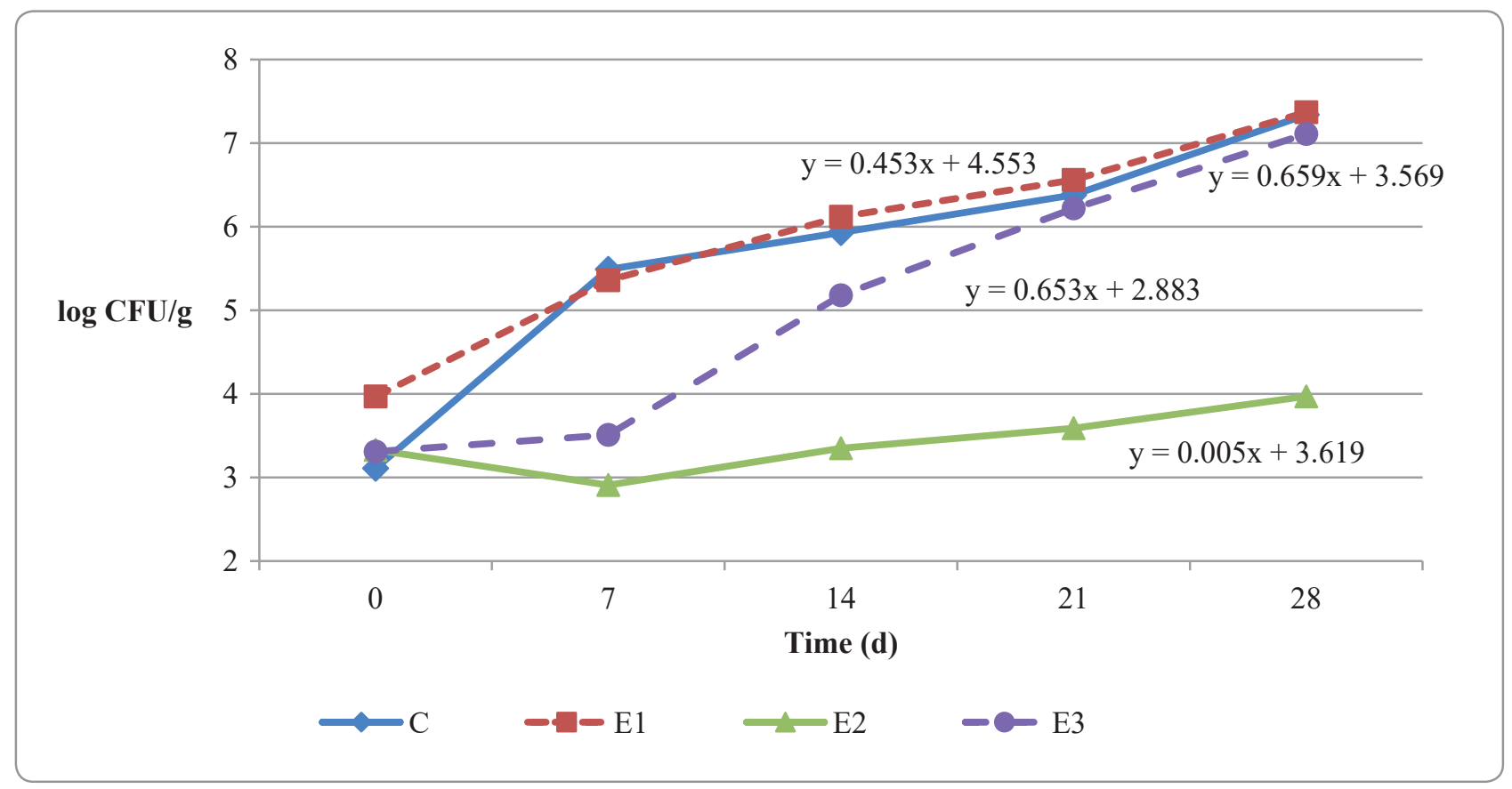

Figure 4. Anaerobic bacterial counts (log CFU/g) in control (C) and marinated (E1, E2 and E3) vacuum-packaged skinless chicken breast fillets $(n=120)$ 
The LAB count increased during the storage of chicken breast fillets in all marinade treatments, except in E2 fillets. The addition of $2 \%$ sodium citrate inhibited LAB growth, and numbers ranged from 2.33 to $2.90 \log \mathrm{CFU} / \mathrm{g}$ during the storage (Fig. 3, Table 1). Many previous studies show that any type of marination treatment, either alone or in combination with other treatments such as vacuum packaging, influences the decrease of LAB (Piñon et al., 2015; Oral et al., 2009; Skandamis et al., 2002; Nieminen et al., 2012). Rouger at al. (2017) stated that in different studies on poultry meat spoilage, the number of LAB varied in a very wide range (from not detected to $9.04 \log \mathrm{CFU} / \mathrm{g}$ ). Temperature of storage and duration of study did not affect LAB numbers in numerous studies conducted on marinated chicken (Doulgeraki et al., 2012; Zhang et al., 2012; Capita et al., 2013; Krockel, 2013; Kalschne et al., 2014). Despite their positive effects, some species of LAB are the major spoilage bacteria in vacuum- and modified atmosphere-packaged poultry meat.

Among the studied bacterial groups, the most significant increase detected in our chicken breast fillets was in the anaerobic bacteria, counts of which were higher than $7 \log \mathrm{CFU} / \mathrm{g}$ at the end of storage, with the notable exception of E2 fillets (3.97

Table 1. Total viable count, Enterobacteriaceae count, lactic acid bacteria count and anaerobic bacterial count $(\log \mathrm{CFU} / \mathrm{g})(\overline{\mathrm{X}} \pm \mathrm{Sd})$ on marinated, vacuum-packaged chicken breast fillets during chilled storage

\begin{tabular}{|c|c|c|c|c|}
\hline & C & E1 & $\mathbf{E} 2$ & $\mathbf{E 3}$ \\
\hline \multicolumn{5}{|c|}{ Total viable counts (TVC) } \\
\hline day 0 & $3.40 \pm 0.19 \mathrm{ABCDa}$ & $4.61 \pm 0.76$ АBCDab & $4.04 \pm 0.18 \mathrm{ABC}$ & $3.66 \pm 0.33 \mathrm{ABCb}$ \\
\hline day 7 & $6.29 \pm 0.50$ AEFGab & $6.25 \pm 0.53 \mathrm{Acd}$ & $3.26 \pm 0.42 \mathrm{ADac}$ & $3.83 \pm 0.43^{\text {DEFbd }}$ \\
\hline day 14 & $5.39 \pm 0.25$ ВЕНа & $5.64 \pm 0.24^{\mathrm{BEbc}}$ & $3.39 \pm 0.13$ BEabd & $4.95 \pm 0.54$ ADGHcd \\
\hline day 21 & $5.62 \pm 0.32 \mathrm{CFI}$ & $6.12 \pm 0.10^{\mathrm{CF}}$ & $3.57 \pm 0.25^{\mathrm{C}}$ & $5.86 \pm 0.27 \mathrm{BEG}$ \\
\hline day 28 & $7.03 \pm 0.23 \mathrm{DGHI}$ & $6.94 \pm 0.33$ DEF & $3.91 \pm 0.28 \mathrm{DE}$ & $5.91 \pm 0.20 \mathrm{CFH}$ \\
\hline \multicolumn{5}{|c|}{ Enterobacteriaceae } \\
\hline day 0 & $4.16 \pm 0.43 \mathrm{ABabc}$ & $4.83 \pm 0.50$ Aade & $2.70 \pm 0.26 \mathrm{ABCDbd}$ & $2.64 \pm 0.13 \mathrm{ABce}$ \\
\hline day 7 & $5.71 \pm 0.13$ Aabc & $4.44 \pm 0.45$ ade & $1.01 \pm 0.04$ AEbd & $1.65 \pm 0.63$ CDEce \\
\hline day 14 & $4.19 \pm 0.32 \mathrm{ab}$ & $4.10 \pm 0.05 \mathrm{Acd}$ & $0.54 \pm 0.18$ BEace & $3.02 \pm 1.00$ Cbde \\
\hline day 21 & $5.63 \pm 0.50^{\mathrm{Babc}}$ & $4.72 \pm 0.42$ ade & $0.82 \pm 0.40 \mathrm{Cbdf}$ & $3.79 \pm 0.29$ ADcef \\
\hline day 28 & $4.42 \pm 0.22^{\mathrm{a}}$ & $4.62 \pm 0.43^{\mathrm{bc}}$ & $0.85 \pm 0.32$ Dabd & $3.76 \pm 0.69 \mathrm{BEcd}$ \\
\hline \multicolumn{5}{|c|}{ Lactic acid bacteria (LAB) } \\
\hline day 0 & $2.74 \pm 0.23 \mathrm{ABCD}$ & $2.98 \pm 0.55 \mathrm{AB}$ & $2.89 \pm 0.21 \mathrm{AB}$ & $2.52 \pm 0.15 \mathrm{ABC}$ \\
\hline day 7 & $4.62 \pm 0.46^{\mathrm{AEFabc}}$ & $2.89 \pm 0.18 \mathrm{CDad}$ & $2.33 \pm 0.30 \mathrm{ACDbd}$ & $2.44 \pm 0.21 \mathrm{DEFc}$ \\
\hline day 14 & $4.55 \pm 0.18$ BGHabc & $2.75 \pm 0.35 \mathrm{EFad}$ & $2.37 \pm 0.26^{\mathrm{BEbe}}$ & $3.56 \pm 0.56$ ADGHcde \\
\hline day 21 & $5.50 \pm 0.10^{\text {CEGabc }}$ & $4.92 \pm 0.31$ ACEad & $2.85 \pm 0.43$ Cbde & $4.69 \pm 0.37$ BEGIce \\
\hline day 28 & $5.82 \pm 0.31$ DFHab & $4.97 \pm 0.39$ BDFacd & $2.90 \pm 0.17$ DEbce & $5.53 \pm 0.19$ CFHIde \\
\hline \multicolumn{5}{|c|}{ Anaerobic bacterial counts } \\
\hline day 0 & $3.11 \pm 0.19 \mathrm{ABCDa}$ & $3.97 \pm 0.55$ ABCDabc & $3.33 \pm 0.07 \mathrm{Ab}$ & $3.31 \pm 0.17 \mathrm{ABCc}$ \\
\hline day 7 & $5.49 \pm 0.38$ AEFab & $5.36 \pm 0.47$ AEFGcd & $2.91 \pm 0.32$ BCDace & $3.51 \pm 0.27$ DEFbde \\
\hline day 14 & $5.93 \pm 0.21 \mathrm{BGab}$ & $6.12 \pm 0.18$ BEHcd & $3.35 \pm 0.11$ BEace & $5.18 \pm 0.63$ ADGHbde \\
\hline day 21 & $6.38 \pm 0.65$ СЕНа & $6.56 \pm 0.23 \mathrm{CFIb}$ & $3.59 \pm 0.32 \mathrm{Cabc}$ & $6.22 \pm 0.24$ BEGIc \\
\hline day 28 & $7.34 \pm 0.15$ DFGHa & $7.37 \pm 0.19$ DGHIb & $3.97 \pm 0.30$ ADEabc & $7.11 \pm 0.26^{\text {CFHIc }}$ \\
\hline
\end{tabular}

a, b, c: Means in the same row with the same superscripts are different at $\mathrm{p}<0.05$

A, B, C: Means in the same column with the same superscripts are different at $\mathrm{p}<0.05$

$\mathrm{C}$ - control fillets marinated in a $6 \% \mathrm{NaCl}$ solution; $\mathrm{E} 1$ - fillets marinated in $6 \% \mathrm{NaCl}+2 \%$ sodium tripolyphosphate; E2 - fillets marinated in $6 \% \mathrm{NaCl}+2 \%$ sodium citrate; $\mathrm{E} 3$ - fillets marinated in $6 \% \mathrm{NaCl}, 1 \%$ sodium tripolyphosphate and $1 \%$ sodium citrate. 
$\log$ CFU/g on day 28) (Fig. 4, Table 1). On day 7 in all marinades, the anaerobic bacterial count was significantly lower $(\mathrm{p}<0.05)$ than on other days. These results fully coincide with Piñon et al. (2015), who used ultrasound treatment combined with oregano oil marinade to study the microbiota of poultry breast meat. The anaerobic bacteria present in poultry meat are responsible for the production of large quantities of gases $\left(\mathrm{H}_{2}\right.$ and $\left.\mathrm{CO}_{2}\right)$, which can cause deformation of the vacuum packaged meat due to their accumulation, putrid odours, the presence of exudates, extensive proteolysis and changes in $\mathrm{pH}$ and colour (Yang et al., 2014; Iulietto et al., 2015).

\section{Conclusion}

Based on the microbiological data obtained, the combination of $6 \% \mathrm{NaCl}$ and $2 \%$ sodium citrate is the most appropriate marinade option for reducing the growth of the examined bacterial groups in vacuum-packaged marinated chicken breast fillets during chilled storage. Further studies should be conducted to determine the best composition of marinade to reduce the microbiota present in poultry meat. Also it is important to establish what type of packaging can improve shelf-life and sensory attributes of poultry meat.

\title{
Redukcija mikroflore u mariniranim filetima pilećih grudi pakovanih u vakuum
}

\author{
Jelena Janjić, Jelena Ćirić, Slaven Grbić, Marija Bošković, Milica Glišić, Radmila Mitrović, \\ Adriana Radosavac, Milan Ž. Baltić
}

A p s tr a kt: Cilj ovog rada bio je da se utvrdi uticaj različitog načina mariniranja na mikrobiotu fileta grudi brojlera pakovanih $u$ vakuum $i$ čuvanih pri $4^{\circ} \mathrm{C}$. Ispitivane su tri vrste marinade. Ukupno 120 uzoraka (korišćenih za dva ponavljanja) marinirano je u kontrolnom $(6 \% \mathrm{NaCl}$ ) i tri različita tretmana: $6 \% \mathrm{NaCl} \mathrm{i} 2 \%$ natrijum tripolifosfat (E1), $6 \% \mathrm{NaCl}$ i $2 \%$ natrijum citrat (E2) $\mathrm{i}$ rastvor sa $6 \% \mathrm{NaCl}, 1 \%$ natrijum tripolifosfata i 1\% natrijum citrata (E3). Brojanje mikroorganizama vršeno je prvog dana (0 dan), $7 ., 14 .$, 21. i 28. dana skladištenja. Utvrđene su statistički značajne razlike $(P<0,05)$ između mariniranih uzoraka u ukupnom broju mezofilnih bakterija, Enterobacteriaceae, bakterijama mlečne kiseline i anaerobnim bakterijama. Utvrđeno je da je kombinacija $6 \% \mathrm{NaCl}$ i $2 \%$ natrijum citrata najprikladnija za redukciju rasta ispitivanih grupa bakterija u mariniranim filetima grudi brojlera pakovanih u vakuum i skladištenih pri $4^{\circ} \mathrm{C}$.

Ključne reči: meso živine, rok trajanja, bakterije kvara, uslovi skladištenja.

Disclosure Statement: No potential conflict of interest was reported by the authors.

Acknowledgement: This paper was supported by the Ministry of Education, Science and Technological Development, government of the Republic of Serbia, through the funding of the Project TR 31034.

\section{References}

Al-Nehlawi, A., Saldo, J., Vega, L. F. \& Guri, S. (2013). Effect of high carbon dioxide atmosphere packaging and soluble gas stabilization pre-treatment on the shelf-life and quality of chicken drumsticks. Meat Science, 94(1), 1-8.

Balamatsia, C. C., Patsias, A., Kontominas, M. G. \& Savvaidis, I. N. (2007). Possible role of volatile amines as quality-indicating metabolites in modified atmosphere-packaged chicken fillets: Correlation with microbiological and sensory attributes. Food Chemistry, 104(4), 1622-1628.

Baltic, T., Baltic, M., Misic, D., Ivanovic, J., I., Janjic, J., Boskovic, M. \& Dokmanovic, M. (2015). Influence of marination on Salmonella spp. growth in broiler breast fillets. Acta veterinaria-Beograd, 65(3), 417-428.
Buses, H. \& Thompson, L. (2003). Dip application of phosphates and marinade mix on shelf life of vacuum-packaged chicken breast fillets. Journal of Food Protection, 66(9), 1701-1703.

Capita, R., Álvarez-Fernández, E., Fernández-Buelta, E., Manteca, J. \& Alonso-Calleja, C. (2013). Decontamination treatments can increase the prevalence of resistance to antibiotics of Escherichia coli naturally present on poultry. Food Microbiology, 34(1), 112-117.

Chouliara, E., Karatapanis, A., Savvaidis, I. N. \& Kontominas, M. G. (2007). Combined effect of oregano essential oil and modified atmosphere packaging on shelf-life extension of fresh chicken breast meat, stored at 4 C. Food Microbiology, 24(6), 607-617. 
Doulgeraki, A. I., Ercolini, D., Villani, F. \& Nychas, G. J. E. (2012). Spoilage microbiota associated to the storage of raw meat in different conditions. International Journal of Food Microbiology, 157(2), 130-141.

Ercolini, D., Russo, F., Torrieri, E., Masi, P. \& Villani, F. (2006). Changes in the spoilage-related microbiota of beef during refrigerated storage under different packaging conditions. Applied and Environmental Microbiology, 72(7), 4663-4671.

Hollingsworth, P. (2000). Marketing trends fueling healthful foods success. Food Technology, 54(10), 53-59.

Iulietto, M. F., Sechi, P., Borgogni, E. \& Cenci-Goga, B. T. (2015). Meat spoilage: a critical review of a neglected alteration due to ropy slime producing bacteria. Italian Journal of Animal Science, 14(3), 4011.

Jay, J. M. (2000). Modern food microbiology. Gaithersburg. Maryland: Aspen Publishers Inc.

Kalschne, D. L., Geitenes, S., Veit, M. R., Sarmento, C. M. \& Colla, E. (2014). Growth inhibition of lactic acid bacteria in ham by nisin: a model approach. Meat Science 98:744752.

Kim, H. Y., Kim, K. J., Lee, J. W., Kim, G. W., Choe, J. H., Kim, H. W., Yoon Y \& Kim, C. J. (2015). Quality characteristics of marinated chicken breast as influenced by the methods of mechanical processing. Korean Journal for Food Science of Animal Resources, 35(1), 101.

Kreyenschmidt, J., Hubner, A., Beierle, E., Chonsch, L., Scherer, A. \& Petersen, B., (2010). Determination of the shelf life of sliced cooked ham based on the growth of lactic acid bacteria in different steps of the chain. Journal of Applied Microbiology 108, 510-520.

Krockel, L., (2013). The role of lactic acid bacteria in safety and flavour development of meat and meat products, lactic acid bacteria. In: M. Kongo (ed.), Lactic acid bacteria - R \& D for food, health and livestock purposes. InTech Publisher, 129-152.

Marenzi, C., (1986). Proper meat storage prevents spoilage. Poultry Misset 6, 12-15.

Mathew, R., Jaganathan, D. \& Anandakumar, S. (2016). Effect of vacuum packaging method on shelf life of chicken. Imperial Journal of Interdisciplinary Research, 2(1), 1859-1866.

Paper received: 16.05.2019.

Paper corrected: 31.05.2019.

Paper accepted: 31.05.2019.
Nieminen, T. T., Välitalo, H., Säde, E., Paloranta, A., Koskinen, K. \& Björkroth, J. (2012). The effect of marination on lactic acid bacteria communities in raw broiler fillet strips. Frontiers in Microbiology, 3, 376.

Nychas, G. J. E., Skandamis, P. N., Tassou, C. C. \& Koutsoumanis, K. P. (2008). Meat spoilage during distribution. Meat Science, 78, 77-89.

Oral, N., Vatansever, L., Sezer, C., Aydın, B., Güven, A., Gülmez, M., Başer K.H. \& Kürkçüoğlu, M. (2009). Effect of absorbent pads containing oregano essential oil on the shelf life extension of overwrap packed chicken drumsticks stored at four degrees Celsius. Poultry Science, 88(7), 1459-1465.

Petracci, M., Laghi, L., Rimini, S., Rocculi, P., Capozzi, F. \& Cavani, C. (2014). Chicken breast meat marinated with increasing levels of sodium bicarbonate. The Journal of Poultry Science, 51(2), 206-212.

Piñon, M. I., Alarcon-Rojo A. D., Renteria A. L., Mendez G. \& Janacua-Vidales H.. (2015). Reduction of microorganisms in marinated poultry breast using oregano essential oil and power ultrasound. Acta Alimentaria 44, (4), 527-533.

Rouger, A., Tresse, O. \& Zagorec, M. (2017). Bacterial contaminants of poultry meat: sources, species, and dynamics. Microorganisms, 5(3), 50.

Skandamis, P., Tsigarida, E. \& Nychas, G. E. (2002). The effect of oregano essential oil on survival/death of Salmonella typhimurium in meat stored at $5 \mathrm{C}$ under aerobic, VP/MAP conditions. Food Microbiology, 19(1), 97-103.

Snyder, O. P. (1998). Hazard control with acids. In : HACCP-Based Safety and Quality Assured Retail Food Systems (ed. Hospitality Institute of Technology and Management). Chapter 18, pp. 1-4. Saint Paul, Minnesota.

Woods, L. F. J. \& Church, P. N. (1999). Strategies for extending the shelf-life of poultry meat and products. Poultry Meat Science, 25, 302-303.

Yang, X., Youssef, M.K., Gill, C.O., Badoni, M. \& Lopez-Campos, O. (2014). Effects of meat $\mathrm{pH}$ on growth of 11 species of psychrotolerant clostridia on vacuum packaged beef and blown pack spoilage of the product. Food Microbiology, 39, 13-18.

Zhang, Q. Q., Han, Y. Q., Cao, J. X., Xu, X. L., Zhou, G. H. \& Zhang, W. Y. (2012). The spoilage of air-packaged broiler meat during storage at normal and fluctuating storage temperatures. Poultry Science, 91(1), 208-214. 